Note

\title{
A Hyperthyroid Patient with Graves' Disease Who Was Strongly Resistant to Methimazole: Investigation on Possible Mechanisms of the Resistance
}

\author{
Hua LI, JYOJI OKUDA, TAKASHI AKAMIZU, AND TORU MORI \\ Department of Laboratory Medicine, Faculty of Medicine, Kyoto University, Kyoto 606, Japan
}

\begin{abstract}
We treated a patient who was hyperthyroid due to Graves' disease and strongly resistant to methimazole (MMI): in spite of good compliance, she needed $150 \mathrm{mg}$ of MMI daily to control her hyperthyroidism. To elucidate the reasons of resistance to MMI, her serum and intrathyroidal MMI concentrations were determined by high pressure liquid chromatography (HPLC). After taking a $30 \mathrm{mg}$ dose of MMI, she had a similar serum MMI concentration-time curve to that of a normal subject: drug malabsorption and rapid drug metabolism were not evident when studied after surgical treatment. After her serum containing MMI was incubated with Protein G, the MMI concentration of the fraction not bound to Protein $G$ did not change significantly from that of untreated serum: the possibility of antiMMI IgG antibody production was considered unlikely. Furthermore, the intrathyroidal concentration of MMI in a surgically obtained tissue specimen was $3 \mu \mathrm{g} / \mathrm{g}$ wet tissue and appeared to be comparable with those of other Graves' tissues reported. Considering that the patient had been taking $150 \mathrm{mg}$ per day of MMI by the time of thyroidectomy, her intrathyroidal MMI concentration was relatively low, suggesting possible impairment of intrathyroidal MMI accumulation. The possibilities of impaired intrathyroidal actions and the severity of hyperthyroidism, especially high $\mathrm{T}_{3}$ levels, also remained as possible causes. In conclusion, here was a severely hyperthyroid patient who was poorly responsive to conventional doses of MMI, and impairment of thyroid uptake of MMI or of pathways after uptake were considered as possible mechanisms.
\end{abstract}

Key words: 2-Methylmercaptoimidazole (MMI), Drug resistance, Graves' disease

(Endocrine Journal 42: 697-704, 1995)

\begin{abstract}
ANTITHYROID drugs have been prescribed quite routinely for the treatment of Graves' disease since their development in the mid-1940s [1]. There are two basic types of antithyroid drugs: the thiouracils and the imidazoles. Propylthiouracil (PTU) and 2-methylmercaptoimidazole (MMI) are the conventionally available members of the former and latter type, respectively. Generally, these drugs inhibit thyroid hormone synthesis leading to a gradual decrease in the serum thyroid hormone level. Both PTU and MMI are very effective in

Received: December 12, 1994

Accepted: May 18, 1995

Correspondence to: Dr. Toru MORI, Department of Laboratory Medicine, Faculty of Medicine, Kyoto University, Sakyo-ku, Kyoto 606, Japan
\end{abstract}

controlling hyperthyroidism due to Graves' disease [1]. MMI is regarded as being about 10-15 times more potent than PTU. Although doses of PTU as high as $2000 \mathrm{mg}$ daily have been used in some patients who are resistant to PTU [2, 3], daily doses of MMI above $60 \mathrm{mg}$ are seldom needed [1].

Recently, we treated a hyperthyroid patient with Graves' disease who was strongly resistant to MMI and needed $150 \mathrm{mg}$ of MMI per day to achieve a euthyroid state. In search for the causes of such resistance to $\mathrm{MMI}$, we measured her serum and intrathyroidal concentrations of MMI by HPLC: the possibilities of abnormal drug metabolism and antiMMI antibody production were examined. 


\section{Materials and Methods}

\section{Patient A}

Clinical course: A 23-year-old female, Patient A, had suffered from hyperthyroidism since October, 1992. The diagnosis of hyperthyroidism was made on the base of typical clinical manifestations including exophthalmos, high serum thyroid hormone concentrations $\left(\mathrm{FT}_{4} 10 \mathrm{ng} / \mathrm{dl}, \mathrm{T}_{3} 912 \mathrm{ng} /\right.$ $\left.\mathrm{d} l, \mathrm{~T}_{4} 31.3 \mu \mathrm{g} / \mathrm{d} l\right)$, increased thyroid ${ }^{99 \mathrm{~m}} \mathrm{Tc}$ pertechnetate uptake $(20.48 \%)$ and suppression of serum $\mathrm{TSH}(<0.03 \mu \mathrm{U} / \mathrm{ml})$. Thyrotropin binding inhibitor immunoglobulin (TBII) measured with a radioreceptor assay kit was $83.9 \%$, anti-thyroid microsomal antibody was $6400 \times$ and anti-thyroglobulin antibody was negative. She had normal renal and liver functions and was not receiving any other drugs. The clinical course is shown in Fig. 1. At first, a $30 \mathrm{mg}$ daily dose of MMI (Chugai Corp. Japan) was given and she became euthyroid after about 5 weeks. However, despite good drug compliance, the patient became hyperthyroid again 3 weeks later. Then the dose was increased to 75 mg per day which was effective to a limited extent, and an increase in serum $\mathrm{T}_{4}$ and $\mathrm{T}_{3}$ was seen after another 4 weeks. In such a case, good drug compliance is quite indispensable. The attending physician (J. Okuda) repeatedly explained this and the patient followed his instructions faithfully because she did not want to have surgical treatment until the very end of her clinical course. She had never suffered from nausea or vomiting. She was considered to be reliable and to have followed the physician's instructions. $100 \mathrm{mg}$ per day of MMI produced a quite similar pattern, and a daily dose of $150 \mathrm{mg}$ (q.i.d.: $35 \mathrm{mg}, 35 \mathrm{mg}, 40 \mathrm{mg}, 40 \mathrm{mg}$ ) had been given since April 16, 1993. This dose of MMI appeared effective. Patient A was hospitalized on May 14, 1993 and took the drug in the presence of a nurse, but when the dose was reduced to $75 \mathrm{mg}$ for a week, her thyroid state worsened again. Since June 7 th, she was kept euthyroid with $150 \mathrm{mg}$ of MMI and an additional $450 \mathrm{mg}$ dose of PTU followed by 15 drops of Lugol's solution per day.

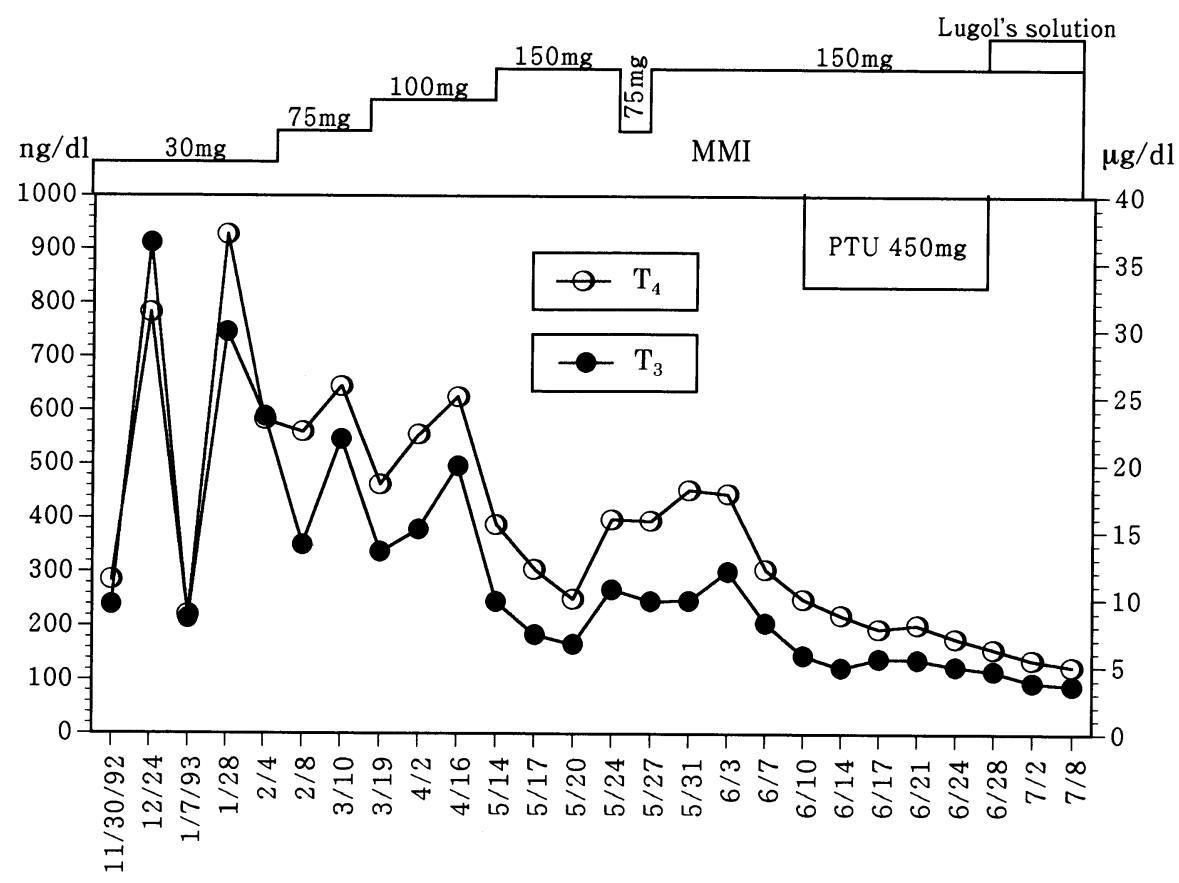

Fig. 1. The clinical course of Patient A. Since Nov. 30, 1992, a $30 \mathrm{mg}$ daily dose of methimazole (MMI) had been taken by Patient A. Treatment with antithyroid drugs and alterations of $T_{3}$ and $T_{4}$ were demonstrated. Patient $A$ was hospitalized on May 14, 1993. Since June 7 th, she had been kept normal serum $\mathrm{T}_{3}$ and $\mathrm{T}_{4}$ levels with $150 \mathrm{mg}$ of MMI and an additional $450 \mathrm{mg}$ dose of PTU followed by 15 drops of Lugol's solution per day. Subtotal thyroidectomy was performed on July 8 th. 
Perchlorate discharge test was performed during the administration of $150 \mathrm{mg}$ of MMI, and was positive at $14.6 \%(30 \mathrm{~min})$ and $13.6 \%(60 \mathrm{~min})$. In our hospital, an abnormal test result was defined as the discharge of ${ }^{123} \mathrm{I}$ from the thyroid greater than $10 \%$ one hour after the administration of $1 \mathrm{~g}$ of $\mathrm{KClO}_{4}$. Subtotal thyroidectomy was performed successfully on July 8 th. Thyroid weight was estimated to be $46 \mathrm{~g}$ and no particular abnormality related to vascularity, color, consistency or adhesions was noted by the surgeons. Four $g$ of her thyroid gland was left after surgery. She is now in good health and taking $100 \mu \mathrm{g}$ of L-thyroxine per day.

Before the operation, a sample of the patient's venous blood was drawn off $3 \mathrm{~h}$ after oral administration of $35 \mathrm{mg}$ MMI and the MMI concentration in the serum was determined. The serum samples obtained after surgery were used for the recovery test.

The reference ranges for $\mathrm{FT}_{4}, \mathrm{~T}_{4}, \mathrm{~T}_{3}, \mathrm{TSH}$ and TBII were $0.99-1.92 \mathrm{ng} / \mathrm{d} l, 5.0-11.0 \mu \mathrm{g} / \mathrm{d} l, 94-154$ $\mathrm{ng} / \mathrm{dl}, 0.3-3.90 \mu \mathrm{U} / \mathrm{m} l$ and less than $10 \%$, respectively.

Thyroid tissue and preparation of the homogenate: A final dose of $50 \mathrm{mg} \mathrm{MMI}$ and 5 drops of Lugol's solution were given $14 \mathrm{~h}$ before excision. About $2 \mathrm{~g}$ of thyroid tissue was obtained from the excised tissue specimen and stored at $-80^{\circ} \mathrm{C}$ without light exposure.

The thyroid homogenate was prepared as follows. Thyroid tissue $(1 \mathrm{~g})$ was cut into pieces and $1 \mathrm{ml}$ of $0.05 \mathrm{M} \mathrm{Na}-\mathrm{KHPO}_{4}$ buffer, $\mathrm{pH} 4.0$ was added. Then the mixture was homogenized with a 10 $\mathrm{mm}$ diameter glass homogenizer. The homogenate was centrifuged at $1 \times 10^{5} \mathrm{~g}$ at $4{ }^{\circ} \mathrm{C}$ for $1 \mathrm{~h}$. The cytoplasmic layer was collected and passed through a $0.22 \mu \mathrm{m}$ filter.

\section{Determination of MMI in serum and thyroid homogenate}

Chemicals and reagents: MMI (Sigma, USA) and benzamide (BA) (Wako, Japan) were of reagent grade. Acetone, methanol, chloroform and acetonitril (Wako, Japan) were of HPLC grade.

Extraction procedures: $0.4 \mathrm{ml}$ of serum or thyroid homogenate was placed in a stoppered test tube along with $0.1 \mathrm{ml}$ of 125 or $250 \mu \mathrm{g} / \mathrm{ml}$ BA (prepared in mobile phase solutions). BA was used as the internal standard. The mixture was extracted with $0.5 \mathrm{ml}$ of acetone and vortex mixed. The upper layer was obtained after centrifugation (3000 $\mathrm{rpm}, 5 \mathrm{~min}, 4^{\circ} \mathrm{C}$ ) and evaporated off under a stream of oxygen free nitrogen. The above residue was solubilized with $0.5 \mathrm{~m} l$ of water and methanol $(1: 1, V / V)$, dried out and then solubilized with 0.5 $\mathrm{ml}$ of chloroform and dried out again. The last residue was dissolved with $100 \mu l$ of mobile phase solutions, and $10 \mu l$ aliquots were injected onto a HPLC column by a stop flow injection technique. The protein concentration of thyroid homogenate was $60 \mathrm{mg} / \mathrm{ml}$ by Bio-Rad Protein Assay (Richmond).

HPLC conditions: The HPLC analysis was performed in a HITACHI L-6200 high pressure liquid chromatograph, equipped with L4000 UV detector at $254 \mathrm{~nm}$. The column was GS320H (Asahi, Japan). The mobile phase solutions were a mixture of sodium acetate buffer $(0.1 \mathrm{Mol} / \mathrm{L}, \mathrm{pH} 4.0)$ and acetonitril $(95: 5, \mathrm{~V} / \mathrm{V})$. The flow rate was $1.5 \mathrm{ml} /$ min. All the procedures were performed at room temperature.

Standard curves: For the quantitative determination of MMI, the standard curves were prepared by adding $0.2-0.8 \mu \mathrm{g}$ of $\mathrm{MMI}$ and $25 \mu \mathrm{g}$ of BA to 1 $\mathrm{ml}$ of blank serum, or $0.2-3.0 \mu \mathrm{g}$ of $\mathrm{MMI}$ and $50 \mu \mathrm{g}$ of BA to $1 \mathrm{ml}$ of thyroid homogenate. The samples were extracted and chromatographed according to the method described above. The standard curves were obtained by the area under curve (AUC) ratios of MMI to BA plotted against the MMI concentrations (Fig. 2A and B).

\section{Absorption test}

Patient A, a normal healthy volunteer, and another hyperthyroid patient (Patient B) were given a single oral $30 \mathrm{mg}$ dose of MMI. Their venous blood specimens were drawn off at $0,1,2,3,5,12$ $\mathrm{h}$, respectively. The serum concentrations of MMI at each time were determined. The test on Patient A was performed after surgery and her thyroid function was hypothyroid $\left(\mathrm{T}_{4} 1.9 \mu \mathrm{g} / \mathrm{dl}, \mathrm{T}_{3} 40 \mathrm{ng} /\right.$ $\mathrm{d} l$ and TSH $5.4 \mu \mathrm{U} / \mathrm{ml}$ ). The thyroid function of Patient B was mildly hyperthyroid at the test $\left(\mathrm{T}_{4}\right.$ $13.9 \mu \mathrm{g} / \mathrm{d} l, \mathrm{~T}_{3} 240 \mathrm{ng} / \mathrm{d} l$ and $\mathrm{TSH}<0.05 \mu \mathrm{U} / \mathrm{ml}$ ). 
A

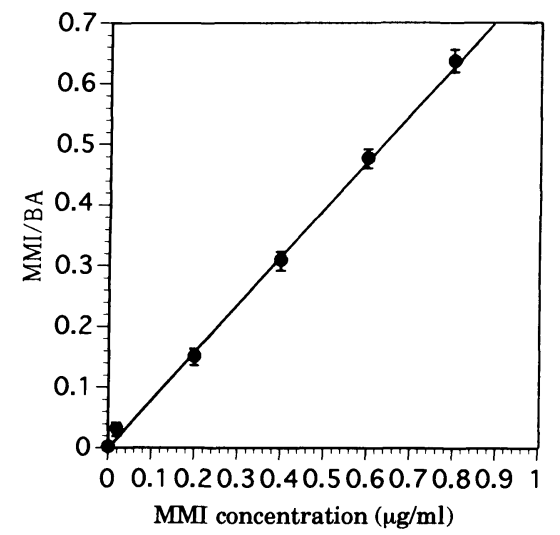

B

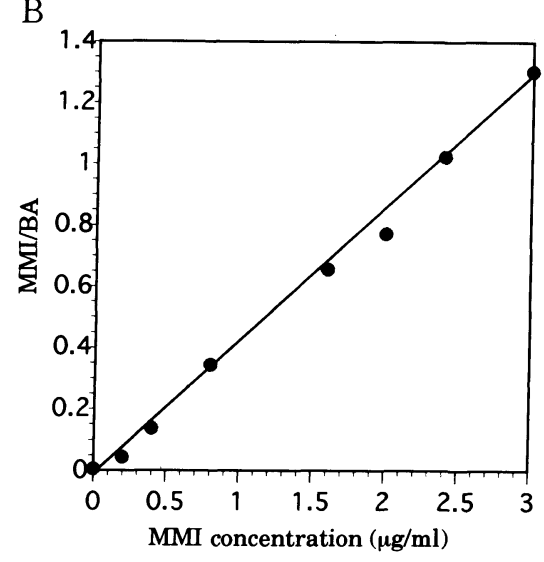

Fig. 2. The typical standard curves for the determination of methimazole (MMI) in serum (A) and thyroid (B). Plots of peak height ratio of $\mathrm{MMI} /$ benzamide (BA) vs. MMI concentration, showing mean \pm SD of triplicate for (A) and mean of duplicate for (B).

\section{Recovery test}

$0.4 \mu \mathrm{g}$ of standard MMI solution was added to 1 $\mathrm{m} l$ each of Patient A's blank serum (after operation) and normal subject's blank serum, respectively. After each serum was incubated for $2 \mathrm{~h}$ at $37^{\circ} \mathrm{C}$ with Protein G (Pharmacia), the MMI concentration of the unbound fraction was determined.

\section{Results}

\section{Determination of MMI in serum and thyroid}

Under the conditions for chromatography de-

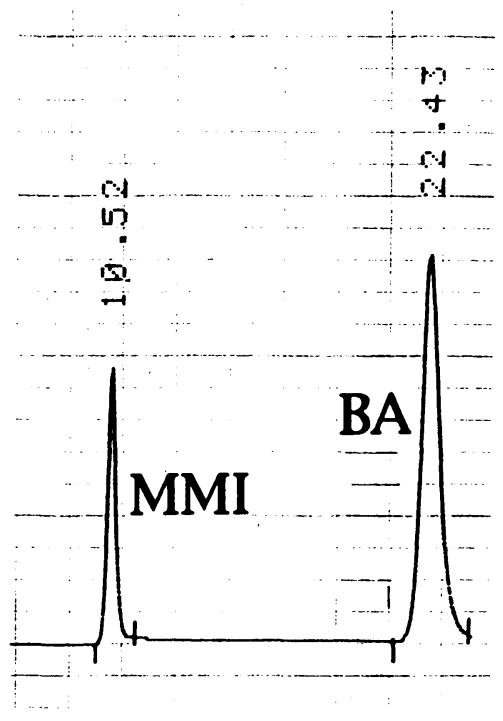

Fig. 3. A chromatogram of standard solution containing methimazole (MMI, $0.8 \mu \mathrm{g} /$ $\mathrm{ml}$ ) and benzamide (BA, $50 \mu \mathrm{g} / \mathrm{ml}$ ). Xand $Y$-axes show elution time and optical density at $254 \mathrm{~nm}$, respectively. The elution times for MMI and BA were approximately 10 and $22 \mathrm{~min}$ respectively. Conditions: mobile phase, $95 \%$ sodium acetate buffer $(0.1 \mathrm{Mol} / \mathrm{L}$, $\mathrm{pH} 4.0) / 5 \%$ acetonitril; flow rate, 1.5 $\mathrm{ml} / \mathrm{min}$; ambient temperature; UVL4000 detector (fixed wave length at $254 \mathrm{~nm}$ ); column, GS320H.

scribed, the elution times for MMI and BA were approximately 10 and 22 min (Fig. 3). The recoveries of MMI and BA through these extraction procedures were $81.5 \%$ and $79.5 \%$ and $83.2 \pm 0.5 \%$ and $82.7 \pm 2.7 \%$ in serum and thyroid homogenate, respectively. The limit of detection for MMI was $20 \mathrm{ng} / \mathrm{ml}$.

Figures 4 and 5 show the representative chromatograms for serum and thyroid extracts. The intra-assay coefficient variations were $6.9 \%$ and $5.2 \%$ at $0.8 \mu \mathrm{g} / \mathrm{ml}$ of MMI for serum and thyroid homogenate, respectively. The serum or intrathyroidal concentration of MMI was calculated by extrapolating the obtained ratios to the standard curve (Fig. 2A, B). The serum concentration of MMI in Patient A was $0.44 \mu \mathrm{g} / \mathrm{ml} 3 \mathrm{~h}$ after $35 \mathrm{mg}$ of MMI before operation. The intrathyroidal concentration of MMI was $3 \mu \mathrm{g} / \mathrm{g}$ wet tissue. 


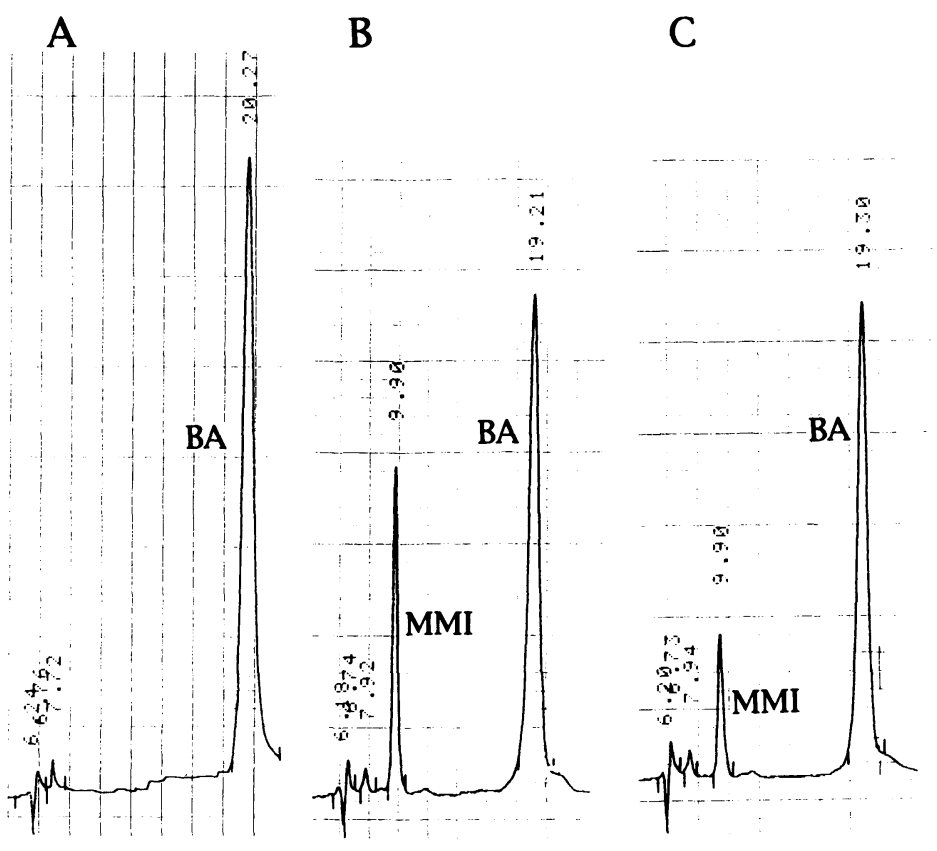

Fig. 4. The chromatograms for sera. (A) extract of blank serum containing benzamide (BA, $25 \mu \mathrm{g} / \mathrm{ml}$ ); (B) extract normal serum containing methimazole (MMI, $0.8 \mu \mathrm{g} / \mathrm{ml}$ ) and benzamide (BA, $25 \mu \mathrm{g} / \mathrm{ml}$ ); (C) extract of Patient A's serum 5 $\mathrm{h}$ after taking $30 \mathrm{mg}$ of MMI containing benzamide (BA, 25 $\mu \mathrm{g} / \mathrm{ml}$ ). The conditions of HPLC and the XY axes are the same as described in Fig. 3.

A

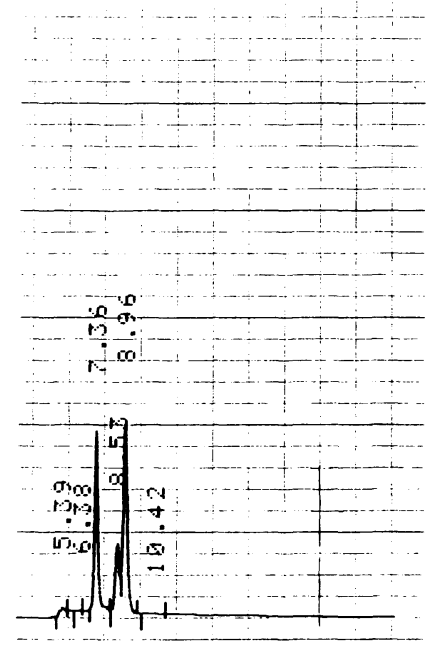

B

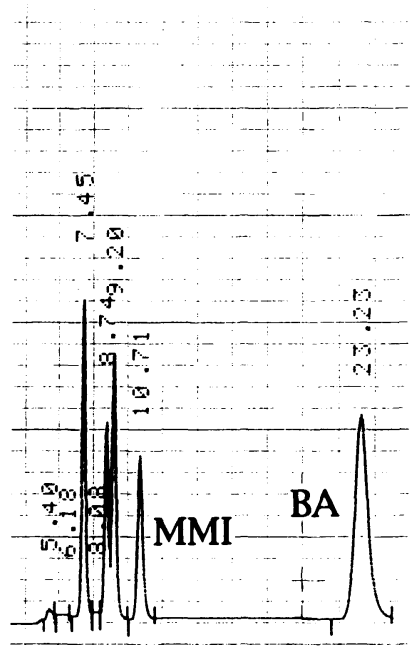

C

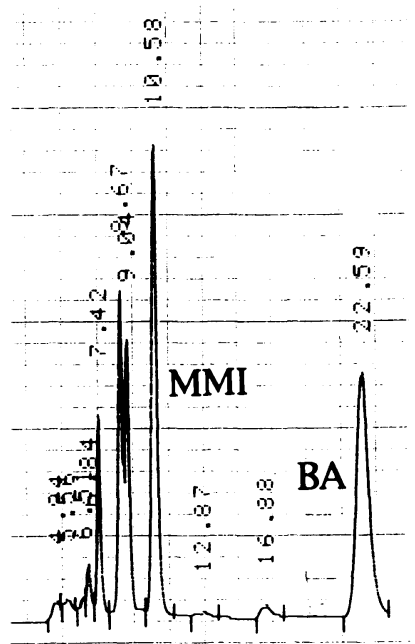

Fig. 5. The chromatograms for thyroid extracts. (A) extract of normal blank thyroid; (B) extract of normal thyroid containing methimazole (MMI, $0.8 \mu \mathrm{g} / \mathrm{ml}$ ) and benzamide (BA, $50 \mu \mathrm{g}$ / $\mathrm{ml}$ ); (C) extract of Patient $\mathrm{A}^{\prime} \mathrm{s}$ thyroid $14 \mathrm{~h}$ after taking $50 \mathrm{mg}$ of MMI containing benzamide (BA, $50 \mu \mathrm{g} / \mathrm{ml}$ ). The conditions of HPLC and the XY axes are the same as described in Fig. 3. 


\section{Absorption test}

To see whether malabsorption of MMI contributed to drug resistance in Patient A, an MMI absorption test was performed. As shown in Fig. 6 , the maximal serum MMI concentration after 30 $\mathrm{mg}$ of MMI administration was $0.48 \mu \mathrm{g} / \mathrm{ml}$ at $2 \mathrm{~h}$ in Patient $\mathrm{A}$. This value was similar to that obtained at $1 \mathrm{~h}$ in a normal subject, $0.45 \mu \mathrm{g} / \mathrm{ml}$. In contrast, in Patient B, the maximal MMI concentration was obtained $3 \mathrm{~h}$ after administration and was very low $(0.13 \mu \mathrm{g} / \mathrm{ml})$. Sequential changes in the serum MMI concentration in Patient $\mathrm{A}$ and a normal subject showed a similar turnover speed, while Patient B had a slower turnover as shown by the disappearance curve. Malabsorption and accelerated elimination of MMI from serum therefore seemed unlikely in Patient A. At the same time, very prolonged turnover of MMI was also not likely.

\section{Recovery test}

To exclude the existence of MMI binding protein, such as anti-MMI antibodies, the recovery test was performed. There was no significant difference between Patient A's MMI serum concentrations before $(0.4 \mu \mathrm{g} / \mathrm{ml})$ and after $(0.38$ $\mu \mathrm{g} / \mathrm{ml}$ ) exclusion of $\operatorname{IgG}$ fractions by Protein $\mathrm{G}$, as

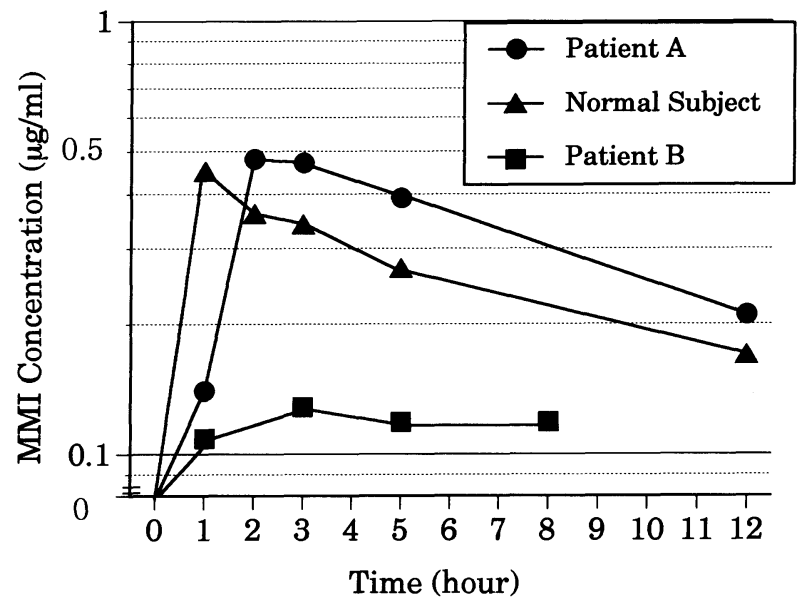

Fig. 6. Serum methimazole (MMI) concentrations in different times $(0,1,2,3,5,12 \mathrm{~h}$, respectively) after a single oral dose of $30 \mathrm{mg}$ MMI in Patient A (- - ), Normal Subject (- - -) and Patient B (- - -). was the case with normal subject's serum $(0.4 \mu \mathrm{g} /$ $\mathrm{ml}$ and $0.42 \mu \mathrm{g} / \mathrm{ml}$, respectively). The possibility of the existence of an IgG antibody to MMI in Patient $\mathrm{A}^{\prime}$ s serum was ruled out.

\section{Discussion}

MMI and PTU have been used to treat hyperthyroidism due to Graves' disease for about five decades. The common dosage is $15-45 \mathrm{mg}$ of MMI or $300-600 \mathrm{mg}$ of PTU per day [6, 7]. MMI is more potent and rapidly effective than PTU in man [8, 9]. In our patient, $150 \mathrm{mg}$ of MMI per day was needed to achieve normal thyroid function. So far as we know, such strong resistance to MMI appears to be quite rare.

As for possible mechanisms of resistance to MMI, drug malabsorption, accelerated drug removal from serum and the existence of a protein binding to MMI were initially considered. In order to analyze these possibilities, it is essential to measure the serum concentration of MMI in this patient. There have been several methods reported for the determination of MMI. Colorimetric assays [10, 11] lacked the requisite sensitivity and specificity necessary for accurate pharmacological studies. Radioimmunoassay was sufficiently sensitivite and specific [12], but antisera are not yet available. Recently, chromatographic techniques, especially HPLC, have been widely used [13-15]. In this study, we also used HPLC to determine the MMI concentration and obtained quite satisfactory sensitivity and specificity comparable with previous reports $[14,15]$.

The extraction of samples with acetone prior to chloroform resulted in giving a clearer and more stable baseline in the chromatogram (Figs. 3, 4 and 5). Following these modifications, MMI was clearly separated from other components present in serum and thyroid homogenate.

The absorption test results obtained after thyroidectomy did not indicate the possibility either drug malabsorption or accelerated drug elimination from the circulation: Patient A had a similar serum concentration and kinetics of MMI to a normal subject after the administration of $30 \mathrm{mg}$ MMI (Fig. 6). Another hyperthyroid Graves' patient, Patient B, had even lower serum concentrations and slower turnover than Patient A and a normal subject studied, though their experimental condi- 
tions varied and the number of cases studied was limited. Nevertheless, our observations do not conflict with those by Dr. Abe et al. [16]. They recently reported that the maximum concentration of MMI was $0.14 \pm 0.073 \mu \mathrm{g} / \mathrm{ml}(\mathrm{n}=3) 2 \mathrm{~h}$ after the administration of $15 \mathrm{mg}$ of MMI. Patient A as well as the normal subject in our study had concentrations more than twice as high $2 \mathrm{~h}$ after the administration of a $30 \mathrm{mg}$ dose. Furthermore, the recovery test excluded the existence of anti-MMI IgG antibody. As for the presence of an MMI binding protein other than IgG, an abnormal accumulation of MMI in her serum before the operation was not seen and $0.44 \mu \mathrm{g} / \mathrm{ml} 3 \mathrm{~h}$ after $35 \mathrm{mg}$ MMI was obtained. This value was compatible with the results of the absorption test performed after the operation. Furthermore, no abnormally prolonged turnover of MMI in serum was observed, as shown in Fig. 4.

We next postulated decreased accumulation of MMI in the thyroid gland of Patient A. Since MMI is presumed to be actively trapped by the thyroid gland [17], impaired uptake of MMI by the thyroid may cause a poor response to MMI. Several investigators have previously reported intrathyroidal MMI concentrations in Graves' patients as 1.13-2.72 [4], 1.46-5.17 [5] and 0.23-1.90 $\mu \mathrm{g} / \mathrm{g}$ tissue [18]. A recent report on Japanese Graves' patients also showed that intrathyroidal MMI concentrations $24 \mathrm{~h}$ after $15 \mathrm{mg}$ of MMI administration were $0.49-2.12 \mu \mathrm{g} / \mathrm{g}$ tissue $(\mathrm{n}=4)$ [16]. Their individual differences were rather large, probably because they might be affected by various factors such as iodine intake, thyroid iodine content, the levels of TSH or thyroid stimulating antibodies, and intrathyroidal metabolism of MMI. The intrathyroidal MMI concentration of Patient A was $3.0 \mu \mathrm{g} / \mathrm{g}$ which is in the upper range or a little higher than in previous reports. Considering the fact that Patient A was taking a $150 \mathrm{mg}$ daily dose of MMI while most patients reported should have taken a much smaller daily dose of MMI, at most $1 / 5$ to $1 / 30$ of that of Patient A, the possibility of impaired accumulation of $\mathrm{MMI}$ in the thyroid gland is considered to be one of the causative factors in the resistance in this patient.

Other possible reasons for MMI resistance are the impaired intrathyroidal action of MMI and the severity of the disease. MMI is concentrated and acts as a peroxidase inhibitor to inhibit the biosynthesis of thyroid hormones in the thyroid [4, 7].
An impairment in the pathway of MMI action would cause resistance to MMI in the patient. A weakly positive perchlorate discharge test result may support this speculation. Very rapid degradation of MMI in the thyroid gland should also be considered, because most metabolites cannot be detected by the present HPLC procedures. Because of the shortage of the thyroid tissue available, we could not measure peroxidase activity in her thyroid. Alternatively, the severity of the disease especially the $T_{3}$ levels might also be a reason for poor response to MMI. O'malley et al. [19] found that conventional doses of carbimazole are not always an adequate starting dose in the treatment of thyrotoxicosis, and higher doses may be advisable for patients with more severe hyperthyroidism. Dahlberg et al. [20] also found that the failure of MMI in the treatment of hyperthyroidism was not due primarily to aberrations in drug metabolism, but rather to the severity of the disease, especially the $T_{3}$ level. When the pretreatment $T_{3}$ value is above $9.0 \mathrm{nMol} / \mathrm{L}$, the patient should receive higher than conventional doses of an antithyroid drug. Pretreatment $\mathrm{T}_{3}$ of Patient A was $912 \mathrm{ng} / \mathrm{ml}(13.3$ $\mathrm{nMol} / \mathrm{L}$ ) and compatible with the above criteria.

Finally, compliance should be questioned. Cooper pointed out that noncompliance is the most likely reason [3]. As shown in Fig. 1, there was an obvious fluctuation of serum $\mathrm{T}_{3}$ and $\mathrm{T}_{4}$ levels during the first 2 months. This may suggest the irregular intake of MMI in Patient A. However, after that serum $T_{3}$ and $T_{4}$ were kept in high levels about 10 weeks in the dose of 75-100 mg per day of MMI. When the dose of MMI was increased to $150 \mathrm{mg}$ per day, serum $\mathrm{T}_{3}$ and $\mathrm{T}_{4}$ decreased gradually and became normal. This indicates that Patient A took MMI regularly. Furthermore, patient A was considered by her physician to be reliable and took drug in the presence of a nurse during admission.

In conclusion, we measured the MMI concentrations in the sera and thyroid of Patient A, and could not find any indication of malabsorption, accelerated removal from blood, or the existence of abnormal binding substances. Further studies will be needed to clarify the mechanism of MMI resistance. This was a hyperthyroid patient who showed strong resistance to MMI, needed $150 \mathrm{mg}$ MMI to achieve a euthyroid state and did not exhibit any evident of side effects. 


\section{Acknowledgments}

We wish to thank Mr. Yoshimichi Ueda (Ishihara Industrial Co., Kusatsu, Japan) for his excellent technical assistance and for supplying a GS320 column. We also thank Dr. Norihiko Murakami for providing Patient B's sera.

\section{References}

1. Cooper DS (1991) Treatment of thyrotoxicosis. In: Braverman LE, Utiger RD (eds) Werner and Ingbar's the Thyroid: a fundamental and clinical text. 6th ed. J. B. Lippincott Company, Philadelphia: 887916.

2. Kuma K, Matsuzuka H, Tamai H (1982) A patient with Graves' disease unresponsive to massive dose of propylthiouracil. Clin Endocrinol (Tokyo) 30: 136139 (In Japanese).

3. Cooper DS (1985) Propylthiouracil levels in hyperthyroid patients unresponsive to large doses. Ann Intern Med 102: 328-331.

4. Okuno A, Yano K, Inyaku F, Suzuki Y, Sanae N, Kumai M, Naith Y (1987) Pharmacokinetics of methimazole in children and adolescents with Graves' disease. Acta Endocrinologica (Copenh) 115: 112-118.

5. Huang GL, Zhang KZ, She YY, Chen DL, Lin ZZ, Chen MA (1990) Studies on intrathyroidal concentrations of methimazole in patients with Graves' disease treated with different doses of methimazole. Abstract of the Second China-Japan Thyroid Conference, Shanghai China, p. 16 (Abstract).

6. Cooper DS (1984) Antithyroid drugs. N Engl J Med 311: 1353

7. Solomon B, Glinoer D, Lagasse R, Wartofsky L (1990) Current trends in the management of Graves' disease. J Clin Endocrinol Metab 70: 1518.

8. Nakashima T, Taurog A, Riesco G (1978) Mechanism of action of thioureylene drugs: factors affecting intrathyroidal metabolism of propylthiouracil and methimazole in rats. Endocrinology 103: 2187.

9. Okamura K, Ikenoue H, Shiroozu A, Sato K, Yoshinari M, Fujishima M (1987) Reevaluation of the effects of methylmercaptoimidazole and propylthiouracil in patients with Graves' hyperthyroidism. J Clin Endocrinol Metab 65: 719.

10. Pittman JA, Beschi RJ, Smitherman TC (1971) Methimazole: its absorption and excretion in man and tissue distribution in rats. J Clin Endocrinol 33:
182.

11. Vesell ES, Shapiro JR, Passananti GT, Jorgensen H, Shively CA (1975) Altered plasma half-lives of antipyrine, propylthiouracil, and methimazole in thyroid dysfunction. Clin Pharmacol Ther 17: 48.

12. Cooper DS, Bode HH, Nath B, Saxe V, Maloof F, Ridgway EC (1984) Methimazole pharmacology in man: studies using a newly developed radioimmunoassay for methimazole. J Clin Endocrinal Metab 58: 473.

13. Skellern GG, Knight BI, Stenlake JB (1976) Improved method for the determination of methimazole in plasma by high-performance liquid chromatography. J Chromatogr 124: 405.

14. Okuno A, Yano K, Inyaku F, Suzuki $Y$, Taguchi $T$, Murata M, Monotani N (1984) An improved method for plasma methimazole assay and its clinical application. Folia Endocrinol Japon 60: 985 (In Japanese).

15. Okamura Y, Shigemasa C, Tatsuhara T (1986) Pharmacokinetics of methimazole in normal subjects and hyperthyroid patients. Endocrinol Japon 33: 605.

16. Yoshifumi Abe (the 7th Division of Internal Medicine, Tokai University School of Medicine) Personal communication.

17. Lazarus JH, Marchant B, Alexander WD, Clark DH (1975) 35S-antithyroid drug concentration and organic binding of iodine in the human thyroid. Clin Endocrinol (Oxf) 4: 609.

18. Jansson R, Dahlberg PA, Johansson H, Lindstrom $B$ (1983) Intrathyroidal concentrations of methimazole in patients with Graves' disease. J Clin Endocrinol Metab 57: 129.

19. O'malley BP, Rosenthal FD, Northover BJ, Jennings PE, Woods KL (1988) Higher than conventional doses of carmbimazole in the treatment of thyrotoxicosis. Clin Endocrinol 29: 281.

20. Dahlberg PA, Karlsson FA, Lindstrom B, Wide L (1981) Studies of thyroid hormone and methimazole levels in patients with Graves' disease on a standardized antithyroid drug regimen. Clin Endocrinol 14: 555 . 